\title{
Public education supply and student performance
}

\author{
MICHAEL L. MARLOW
} College of Business, California Polytechnic State University, San Luis Obispo,
CA 93407, USA

This paper develops a model of public exchange whereby voters and education policy makers exchange with one another within school districts. Because school district consolidation lowers alternatives to voters-parents, consolidation is hypothesized to raise public education spending because weakened intergovernmental competition allows policy makers to promote their own utility, rather than that of constituents. Models of public education spending and academic performance are estimated over 1988-1990. While evidence indicates little support for the traditional treatment of the Leviathan hypothesis that greater competition lowers public spending, this paper argues that education spending by itself does not fully provide a valid test of the Leviathan hypothesis since spending, by itself, does not necessarily indicate the quality of public education programmes. Empirical evidence indicates that greater numbers of schools and school districts promote higher student achievement as evidenced by higher math and verbal SAT scores, math proficiency of 8th graders, and lower high school drop-out rates. Evidence therefore suggests that, while greater numbers of school districts and schools are, to some degree, associated with higher public education spending, higher student achievement appears to follow as well.

\section{INTRODUCTION}

There is growing perception that the educational system of the United States is in decline and, because the public sector is the dominant supplier of education, criticism naturally focuses on the public school system. While it is often argued that spending has declined, public education spending (1989-90 dollars) per pupil rose 74\% from 1960 to 1992, or from roughly \$2979 to $\$ 5196$. $^{1}$ Despite this spending increase, combined SAT (Student Achievement Test) scores fell $5.2 \%$, or from 948 to 899 over this same period. ${ }^{2}$

Two structural characteristics describe the delivery of primary and secondary levels of public education in the
United States. The first arises because public schools provide $90 \%$ of primary and secondary education and therefore crowd-out private schools that otherwise might inject greater competition into the education market. Parents must pay twice for education when they send children to private schools since payments for public schools are not voluntary. School choice policies are aimed at curtailing the public education monopoly because they provide public funds for parents who choose private schools for their children. ${ }^{3}$ Until widespread support for such policies arises, the public education sector will likely remain insulated from private competition. The second characteristic follows from dramatic reduction in numbers of public school districts:

${ }^{1}$ Statistical Abstract of the United States, 1993, Tables 221 and 222.

${ }^{2}$ Statistical Abstract of the United States, 1993, Table 265.

${ }^{3}$ California's Education Vouchers Initiative (Proposition 174), which was defeated in 1993, would have offered annual public vouchers of roughly \$2600. Friedman (1962) was an early supporter of such policies. Couch, Shughart and Williams (1993) conclude that school vouchers would create a more competitive environment between private and public schools and therefore improve public school quality because higher competition for students is shown to foster higher educational quality, as measured by test scores of a standardized algebra test given to all public school students in North Carolina. When controlling for many factors, such as per capita spending on public school students, poverty, and educational attainment of parents, public school quality was determined to be positively related to competition, as measured by the percentage of school age children enrolled in private schools in neighbouring private schools. 
from 108579 to 14741 over $1942-1987$. Although some of this consolidation may have been motivated by the argument that greater scale economies would result, public education is now characterized by fewer suppliers.

This paper addresses the second characteristic by developing a model of public exchange whereby voters and education policy makers exchange with one another within school districts. The influence of school district consolidation is examined within the context of the Tiebout (1956) effect whereby voters search for desired public programmes within a system of many competing public suppliers. Because consolidation lowers alternatives to voters-parents and, following the Leviathan model of policy makers (Brennan and Buchanan, 1980), consolidation is hypothesized to raise public education spending because weakened intergovenmental competition allows policy makers to promote their own utility, rather than that of constituents. As a point of departure from earlier studies, this paper argues that, while consolidation is predicted to raise spending, this result does not necessarily coincide with the Leviathan model because higher education spending does not necessarily imply lower quality programmes. Higher spending, by itself does not necessarily imply anything about programme quality. Higher spending could filter down to student learning and reflect higher quality programmes. Of course, higher spending could also simply reflect higher amenities provided to policy makers that may be unrelated to higher quality education. This important distinction is not addressed in the current literature on school consolidation.

Examination of how numbers of schools influence spending and academic performance is another point of departure taken in this paper. During this era of school district consolidation, numbers of schools have dropped as well: from 89024 in 1929 to 61407 in $1989 .{ }^{4}$ Previous studies have implicitly assumed that all schools within a given school district provide identical services to parents. This is unlikely since, even when school districts mandate standardized education policies across all of their schools, it is likely there is some, or much, variety in the teachers, staff, facilities, surrounding neighbourhoods, and students that make up the educational experience. Qualities of individual schools may therefore vary widely within school districts and it is reasonable to test whether numbers of schools exert independent influences on spending and academic performance.

Models of state public education spending and academic performance are estimated over 1988-1990. Examination of how numbers of school districts and schools influence both spending and academic performance will suggest how past consolidation of school districts has influenced the public education system.

\section{EXCHANGE IN PUBLIC EDUCATION MARKETS}

Public education policies arise from exchange between voters and policy makers. Voters, or primarily parents in the case of education, signal preferences to policy makers through voice and exit options. ${ }^{5}$ Voice options include voting and expressing views directly to policy makers. Exit options are primarily influenced by fiscal structure and, under a federalist structure, dissatisfied parents may move from one school district to another as they search for desired education policies. ${ }^{6}$ Exit options may be exercised when parents conclude they cannot effectively influence local educational policies through voice options. Exiting is 'voting-with-your feet' in the model of voter behaviour developed by Charles Tiebout (1956). The Tiebout model predicts that, because citizens search for desired packages of government programmes, like-minded citizens tend to assemble in the same political jurisdiction. One result of this search process is that residents of local governments are fairly uniform in their preferences for public programmes. ${ }^{7}$ Families, for instance, may congregate in communities with many good schools and playgrounds and senior citizens may congregate where there are many adult education classes and stringent noise ordinances. Studies support this conclusion when they find that, when communities with diverse populations have relatively few school districts, there tend to be greater numbers of private schools. ${ }^{8}$ In other words, when numbers of school districts do not adequately support the many tastes of diverse populations, private schools enjoy larger markets for their services.

Two beneficial consequences of parental mobility are likely within a system of many competing school districts. First, parents have many choices and, under certain conditions, mobility leads to a Pareto-efficient equilibrium whereby no parent may leave their school district and, at the same time, gain higher utility. Second, policy makers are more responsive to parental preferences when unhappy parents may easily relocate to competing districts and, in this way, jeopardize funding bases of school districts that lose customers.

School district consolidation is therefore hypothesized to lower exit options by limiting suppliers and, consistent with

\footnotetext{
${ }^{4}$ Tables 85, Digest of Education Statistics, 1993. Excluded from these figures are one-teacher schools which have declined from 149282 to 630 over this same time period.

${ }^{5}$ These options were introduced in Hirschman (1970).

${ }^{6}$ A more detailed examination of the roles of voice and exit is presented in Marlow (1992).

${ }^{7}$ Nelson (1990) examined the variations in local metropolitan governments in 1982 and found support for the hypothesis that larger numbers of governments serve those areas characterized by greater differences among local voters.

${ }^{8}$ See Martinez-Vazquez and Seaman (1985) and Hamilton and Macauley (1991).
} 
the Leviathan model, lead to expanding budgets that reflect narrow interests of policy makers, who may include teachers, union officials, and staff. Further, higher spending reflects higher salaries, shorter working hours, more generous pensions, and other forms of compensation that may bear no relation to the quality of public education. Supporters of this view generally advocate school choice policies because local school officials are hypothesized to be less responsive to demands for higher quality education when there are fewer choices for parents. The Leviathan view is that credible threats of exit are the only effective means of improving programme quality. Because consolidation lowers exit possibilities, this view predicts that policy makers may more easily raise budgets in pursuit of narrow self-interests.

But, while greater consolidation limits exit options, the fact that higher spending may result does not necessarily imply that programme quality does not improve as well. A competing view is that improvements in educational quality require higher salaries, numbers of teachers and school buildings; i.e. public education quality and funding levels are synonymous. Supporters of this view are often critics of school vouchers, but, at the same time, subscribe to the predictions of the Tiebout model. Vouchers lower costs of exiting public school districts since parents are provided subsidies to send their children to private schools within their own communities. Vouchers make it cheaper to send children to competing suppliers - private schools - and parents no longer must move to another public school district when they exit their local public school system, as long as there are quality private schools in their local community. Critics of vouchers are fearful that mass exiting of students will leave public school districts with lower funding, and therefore to an erosion of public education quality. Moreover, since vouchers do not normally cover full tuition costs, poor parents are believed to be less able to afford private schools and therefore, as higher income parents exit the public system, funding bases and quality will erode further.

A related argument is often advocated by proponents of the current public school system: that school district consolidation exploits scale economies that provide cost savings to taxpayers. However, while there may be economies of scale in education, it is questionable that the sizable consolidation of school districts has been prompted entirely by attempts to lower costs. Kenny and Schmidt (1994) argue that attempts to exploit scale economies is only one of three factors that explain much of the decline in the number of US school districts over 1950-1980. The other two factors are growth of state aid, which lowered quality differences between districts, and the growing powers of teachers' unions such as the National Education Association that used consolidation as a means of lowering costs of organizing their membership. This finding is consistent with casual observation showing that public education spending measures, such as spending per pupil, have risen over this era of rapid consolidation. The degree to which consolidation may have led to greater scale economies is therefore open to question because it is likely that consolidation exerts other influences on public school spending. Kenny and Schmidt (1994) find that numbers of school districts in states are always substantially greater than numbers that would be predicted based solely on attempts to gain greater scale economies. Therefore, economies of scale are only one possible factor that determines the relation between school consolidation and spending.

The relationship between educational expenditure and educational quality may also have a close analogue in the regulation literature. The Averch and Johnson (1962) effect, for instance, arises when regulators reward firms that allocate resources toward capital and thus leads to overcapitalization. Daugherty (1984) expands upon this idea by considering how regulation may encourage firms to be inefficient due to the Averch and Johnson effect and various incentives to inflate costs. In the case of education, higher spending may arise from over-capitalization or salaries in excess of productivity and, in such instances, the connection between higher spending and product quality becomes unclear. Another interesting possibility is that school administrators may be rewarded on the basis of spending-per-pupil or teacher-pupil ratios. The point of this discussion is that the relationship between expenditure and quality is unclear without further information on the incentives facing school district administrators.

\section{ESTIMATION OF EDUCATION SPENDING EQUATIONS}

There has been substantial testing of the Leviathan hypothesis that greater intergovernmental competition results in a smaller public sector, as usually evidenced by lower public spending. Empirical evidence is mixed and, in part, arises from different testing methodologies. ${ }^{9}$ Oates (1985), Forbes and Zampelli (1989) and Heil (1991) find no support for the hypothesis. Support, full or partial, is found in Nelson (1986, 1987), Wallis and Oates (1988), Zax (1989) and Raimondo (1989). With the exceptions of Oates (1985) and Heil (1991), which examine cross-national data, these studies focus on state and local governments. Another group of studies, which include the federal government in their testing, report mixed results as well. Support is shown in Marlow (1988), Grossman (1989), Joulfaian and Marlow (1990, 1991) and no support in Oates (1985) and Heil (1991).

\footnotetext{
${ }^{9}$ See Oates (1989) for a discussion of some of these differences.
} 
Several studies specifically examine how numbers of school districts influence public education spending of elementary and secondary schools. Burnell (1991) tests the hypothesis that greater centralization leads to higher expenditures per pupil on a data set of 280 counties from the 1977 Census of Governments. Her model holds constant the following factors: size of county, teacher salary, pupilteacher ratio, property tax base, state education grants, median income, and percentage of students in local populations. Numbers of school districts exert positive and significant influences on per pupil education spending. No support is therefore found for the hypothesis that school district consolidation lowers intergovernmental competition and fosters higher public spending. This result may suggest that consolidation fosters scale economies that results in lower spending.

Kenny and Schmidt (1994) report some evidence that fewer school districts exert significant and positive influences on expenditures per pupil. It should be noted, however, that intergovernmental competition is measured differently than in Burnell (1991): a dummy variable takes a value of 1 when the number of school districts per student in a state is less than the value at the twenty-fifth percentile, and 0 otherwise. Another reason why this study may not support Burnell's is that it uses the state as the unit of observation, rather than counties.

This survey indicates that there is little consistent evidence on the school consolidation issue. This paper argues that, while the Leviathan model predicts that consolidation raises spending, higher spending by itself does not necessarily support the Leviathan model. In addition, the literature implicitly assumes that all schools within a given school district are equal in the eyes of parents. This is unlikely, even though school districts may attempt to standardize education policies across all of their schools. Personalities and qualifications of teachers, staff, students, and day-to-day practices of individual schools are likely to vary widely within large school districts. It is therefore reasonable to test whether numbers of schools exert independent influences on spending and performance. These important issues are now examined in the following manner. First, the relationship between numbers of school districts (and schools) and spending is estimated so that our results may be compared with those previously reported. Second, the relationship between school districts (and number of schools) and student performance is estimated to clarify what effect numbers of suppliers exert on programme quality.
The following models of cross-state education spending are estimated for 1988, 1989 and 1990:

$$
\begin{aligned}
& E X P_{i}=f\left(Y_{i}, E D U C_{i}, D E N S I T Y_{i}, S T U D E N T_{i},\right. \\
& S T_{A T E_{i}}, F_{E} D_{i}, \text { LIBERAL } L_{i}, \text { UNION }_{i} \text {, } \\
& \text { DIS TRIC TS } S_{i} \text {, or SCHOOLS }
\end{aligned}
$$

where

$E X P_{i}$

$Y_{i}$

$E D U C_{i} \quad=$ percentage of population with high school degrees

DENSITY $i=$ percentage of population living in urban areas

$S T U D E N T_{i}=$ student percentage of population

$S T A T E_{i} \quad=$ state share of education funding

$F E D_{i} \quad=$ federal share of education funding

$\operatorname{LIBERAL_{i}}=$ index of liberal tendencies of US Senators

$U_{N I O N_{i}}=$ percentage of wage and salary public employees who are union members

DISTRICTS $T_{i}=$ number of school districts per 1000 students

SCHOOLS $_{i}=$ number of schools per 1000 students

Two measures of education (elementary and secondary) spending are considered: per student and as a percentage of gross state product. ${ }^{10}$ Estimation for three different periods, 1987, 1988 and 1990, is based on ease of data availability. ${ }^{11}$ Significance of estimated coefficients is based on twotailed tests at the 0.01, 0.05, and 0.10 levels. Data for $E X P_{i}, S T U D E N T_{i}, S T A T E_{i}, F E D_{i}$, DISTRICTS $S_{i}$ and $S C H O O L S_{i}$ are obtained from the Digest of Education Statistics $(1992,1993)$. Data on $Y_{i}, E D U C_{i}$, DENSITY $Y_{i}$, are obtained from the Statistical Abstract of the United States (various years). Sources for $L I B E R A L_{i}$ and $U N I O N_{i}$ are discussed below.

The median voter theorem predicts that median voters control spending decisions and median income $Y_{i}$ is therefore hypothesized to be positively related to education spending. Previous studies argue that higher educated voters tend to vote for more education and therefore a positive coefficient is hypothesized for $E D U C_{i}$, average education of the population. Population density DENSITY measures the percentage of the population living in urban areas and, because production costs are commonly believed to be higher in urban areas, it is hypothesized to be positively related to education spending. The student percentage

\footnotetext{
${ }^{10}$ Following the above discussion regarding the nebulous connection between educational expenditure and school quality, education spending was disaggregated into two components: capital outlays as a percentage of total education spending and salaries of teachers as a percentage of total education spending. These data were obtained from the Digest of Education Statistics (1992, 1993). However, in separate estimations (using both OLS and SUR estimation), the measures of competition did not exert statistically significant effects on these disaggregated measures of education spending and are therefore not shown here.

${ }^{11}$ Unfortunately, with such a short time span, and given so little variation in several of the regressors over this short span, a panel model, or time-series cross-section model, was not estimated.
} 
of the population $S T U D E N T_{i}$ controls for cross-state differences in student populations and is hypothesized to exert positive influences on education spending since higher values may reflect greater parental demands for education.

The state share of education funding $S T A T E_{i}$ controls for the Brennan and Buchanan (1980) hypothesis that more centralized funding leads to the perception by taxpayers that local funding burdens are lower than under less centralized funding. ${ }^{12}$ That is, the lower the cost perceived by taxpayers, the greater the demand for public education. Moreover, if higher values of $S T A T E_{i}$ lead to greater spending equalization among schools and school districts, then there may also be fewer quality differences within a state's public education system and therefore fewer potential gains that parents may experience by relocating to another school district or school. The federal share of education funding $F E D_{i}$ is hypothesized to exert similar influences on public education spending.

LIBER $A L_{i}$ is an index of the voting tendencies of US Senators reported in the National Journal. The simple average of the 1986 scores for both Senators in each state is used. An index of 40, for example, means that a Senator is more liberal than $40 \%$ of the Senate on economic issues. This index controls for the possibility that states characterized by more liberal voters might have larger public education budgets as well.

Union effects on education spending follow from studies demonstrating that, when unionized, public sector workers earn higher compensation than when public sector workers are not unionized. For example, firefighters (Ashenfelter, 1971; Ehrenberg, 1973 and Ichniowski, 1980); teachers (Gallagher, 1978), and police officers (Trejo, 1991) have been shown to benefit from unionization in the public sector. Marlow and Orzechowski (1996) find that greater public employee unionization leads to higher overall public spending as well. The percentage of employed wage and salary public employees who are union members $U N I O N_{i}$ measures the role that public employees play in decisions over education spending. An alternative measure, percentage of employed wage and salary workers who are covered by union contracts, was also considered but, because the results do not change, estimations using this alternative measure are not shown here. Data for 1986 provided in Curme, Hirsch and MacPherson (1990) are used since this is the latest available year for this data. While it would be preferable to directly measure union penetration of school employees, these data are not available at the level of the state for years examined in this study.
As previously discussed, the Leviathan model predicts that fewer school districts lead to higher education spending because this reflects less intergovernmental competition in the public education market. The hypothesized sign on

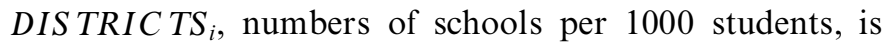
therefore negative. SCHOOLS, numbers of schools per 1000 students, is also separately considered because it is questionable that all schools within given school districts are identical. Greater numbers of $S C H O O L S_{i}$ are hypothesized to lead to lower spending since this indicates greater competition in the public education market.

Initially, OLS estimation was conducted, but given the relatively large number of regressors which appear to be insignificant, estimates which allow for correlation in the error term were generated. The SUR model of seemingly unrelated regressions was estimated and are shown in Tables $1-3 .{ }^{13}$ If the disturbances of the equations are correlated, the SUR estimator is more efficient since it takes the entire matrix of correlations of all equations into consideration.

Table 1 reports SUR estimates of education spending per student equations for 1988, 1989, and 1990. Median income is found to exert the hypothesized positive influence on education spending in four of six equations. Education, urbanization (with one exception), state funding, federal funding, and liberal variables are never statistically significant from zero. Student share of the population exerts a significant and positive influence in three cases. The union variable exerts the hypothesized positive, and statistically significant, influence in all cases. Numbers of school districts never exert significant influences. However, numbers of schools always exert positive and statistically significant influences on education spending and therefore provides evidence counter to the Leviathan model of public spending.

Table 2 reports SUR estimates of education spending as percentages of GSP for 1988, 1989, and 1990. Median income and education exert no significant influences. State funding (with one exception) and union variables never exert significant influences on education spending. Urbanization exerts negative and significant influences in all cases, and is counter to its hypothesized positive influence. Student-shares of population exert expected positive influences on education spending. Negative and significant influences (in all but one case) from federal shares of funding are contrary to expectations. Positive and significant influences from the liberal character of states are as hypothesized. For 1988 and 1989, both numbers of school districts and schools exhibit positive and significant influences on education

\footnotetext{
${ }^{12}$ Winer (1983) and Logan (1986) have argued that higher values of grants lower financing burdens, as perceived by taxpayers, and leads to higher overall government spending.

${ }^{13}$ In comparison to OLS estimation, SUR estimation led to the rejection of the null hypothesis in the case of the $U$ nion variable in Table 1. In Table 2, SUR estimation changed the previously significant coefficients on the Income variable to become insignificant in years 1989 and 1990, and led to the statistical significance of the School competition variable in 1990. In Table 3, SUR estimation changed the income variable from significant in all but one case.
} 


\begin{tabular}{|c|c|c|c|c|c|c|}
\hline \multirow[b]{2}{*}{ Constant } & \multicolumn{2}{|c|}{1988} & \multicolumn{2}{|c|}{1989} & \multicolumn{2}{|c|}{1990} \\
\hline & $\begin{array}{c}439.96^{\mathrm{c}} \\
1.34\end{array}$ & $\begin{array}{r}159.85 \\
0.49\end{array}$ & $\begin{array}{c}497.44^{\mathrm{c}} \\
1.41\end{array}$ & $\begin{array}{r}209.25 \\
0.63\end{array}$ & $\begin{array}{l}5.85^{\mathrm{c}} \\
1.53\end{array}$ & $\begin{array}{r}215.99 \\
0.56\end{array}$ \\
\hline Income & $\begin{array}{l}0.001 \\
0.72\end{array}$ & $\begin{array}{l}0.004^{\mathrm{c}} \\
1.74\end{array}$ & $\begin{array}{l}0.002^{\mathrm{c}} \\
1.72\end{array}$ & $\begin{array}{l}0.001^{\mathrm{a}} \\
2.53\end{array}$ & $\begin{array}{l}0.001 \\
0.87\end{array}$ & $\begin{array}{l}0.01^{\mathrm{b}} \\
2.08\end{array}$ \\
\hline Education & $\begin{array}{r}-2.16 \\
0.35\end{array}$ & $\begin{array}{r}-3.15 \\
0.59\end{array}$ & $\begin{array}{r}-2.78 \\
0.41\end{array}$ & $\begin{array}{r}-3.77 \\
0.67\end{array}$ & $\begin{array}{r}-3.07 \\
0.41\end{array}$ & $\begin{array}{r}-3.45 \\
0.54\end{array}$ \\
\hline Urban & $\begin{array}{r}-1.24 \\
0.70\end{array}$ & $\begin{array}{l}0.35 \\
0.24\end{array}$ & $\begin{array}{r}-1.93 \\
1.00\end{array}$ & $\begin{array}{r}-0.23 \\
0.15\end{array}$ & $\begin{array}{c}-2.81^{\mathrm{c}} \\
1.30\end{array}$ & $\begin{array}{l}0.63 \\
0.35\end{array}$ \\
\hline Student & $\begin{array}{c}11.88^{\mathrm{c}} \\
1.60\end{array}$ & $\begin{array}{r}11.15 \\
1.25\end{array}$ & $\begin{array}{c}11.86^{\mathrm{c}} \\
1.47\end{array}$ & $\begin{array}{r}10.55 \\
1.11\end{array}$ & $\begin{array}{c}14.77^{\mathrm{c}} \\
1.75\end{array}$ & $\begin{array}{r}13.35 \\
1.29\end{array}$ \\
\hline State & $\begin{array}{r}-0.30 \\
0.34\end{array}$ & $\begin{array}{l}0.30 \\
0.29\end{array}$ & $\begin{array}{r}-0.29 \\
0.29\end{array}$ & $\begin{array}{l}0.31 \\
0.29\end{array}$ & $\begin{array}{l}0.33 \\
0.30\end{array}$ & $\begin{array}{l}1.01 \\
0.86\end{array}$ \\
\hline Federal & $\begin{array}{r}-2.62 \\
0.70\end{array}$ & $\begin{array}{r}-4.23 \\
0.76\end{array}$ & $\begin{array}{r}-2.49 \\
0.63\end{array}$ & $\begin{array}{r}-4.60 \\
0.79\end{array}$ & $\begin{array}{r}-6.09 \\
1.20\end{array}$ & $\begin{array}{r}-7.60 \\
1.09\end{array}$ \\
\hline Liberal & $\begin{array}{l}0.14 \\
0.16\end{array}$ & $\begin{array}{l}0.29 \\
0.38\end{array}$ & $\begin{array}{l}0.12 \\
0.12\end{array}$ & $\begin{array}{l}0.32 \\
0.39\end{array}$ & $\begin{array}{l}0.12 \\
0.11\end{array}$ & $\begin{array}{l}0.25 \\
0.27\end{array}$ \\
\hline Union & $\begin{array}{l}5.45^{\mathrm{a}} \\
3.53\end{array}$ & $\begin{array}{l}4.44^{\mathrm{a}} \\
3.32\end{array}$ & $\begin{array}{l}5.87^{\mathrm{a}} \\
3.46\end{array}$ & $\begin{array}{l}4.63^{\mathrm{a}} \\
3.23\end{array}$ & $\begin{array}{l}6.48^{a} \\
3.47\end{array}$ & $\begin{array}{l}5.16^{\mathrm{a}} \\
3.24\end{array}$ \\
\hline Districts & $\begin{array}{r}18.29 \\
0.09\end{array}$ & & $\begin{array}{r}12.67 \\
0.05\end{array}$ & & $\begin{array}{r}11.46 \\
0.40\end{array}$ & \\
\hline Schools & & $\begin{array}{c}54.83^{\mathrm{a}} \\
3.53\end{array}$ & & $\begin{array}{c}57.66^{\mathrm{a}} \\
3.56\end{array}$ & & $\begin{array}{r}59.34^{\mathrm{a}} \\
3.23\end{array}$ \\
\hline $\begin{array}{l}R^{2} \\
\text { s.e.e. } \\
n\end{array}$ & $\begin{array}{r}0.31 \\
141.07 \\
50\end{array}$ & $\begin{array}{c}0.45 \\
126.6 \\
50\end{array}$ & $\begin{array}{c}0.16 \\
141.1 \\
50\end{array}$ & $\begin{array}{c}0.36 \\
136.4 \\
50\end{array}$ & $\begin{array}{c}0.31 \\
170.2 \\
50\end{array}$ & $\begin{array}{c}0.32 \\
151.9 \\
50\end{array}$ \\
\hline
\end{tabular}

$t$-statistics below estimated coefficients.

a, b, c: significance at 1, 5, 10\% levels (2-tailed tests) or greater.

spending. While, in 1990, no significant influence is found in the case of numbers of school districts, numbers of schools exert a positive and significant influence.

\section{Estimation of student performance equations}

So far, some evidence of a positive relationship between public education spending and numbers of school districts and schools has been determined. Although the previous literature would have concluded that this evidence fails to support the Leviathan hypothesis of a negative relationship between public education spending and numbers of competitors, this paper argues that such evidence does not necessarily reject the Leviathan hypothesis. The Leviathan hypothesis also suggests that greater intergovernmental competition, or school competition in this case, fosters higher quality education programmes. The connection between education spending and programme quality is therefore ambiguous. Higher education spending (via greater interschool competition) could simply reflect higher compensation for school personnel or it could also reflect higher quality programmes.
To examine this issue, the following models of cross-state educational performance are estimated:

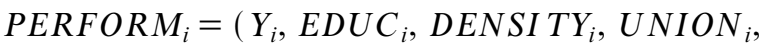

$$
\begin{aligned}
& \text { TAKE }_{i} \text {, DIS TRIC TS } S_{i} \text { or SCHOOLS } \text { S }_{i}
\end{aligned}
$$

The dependent variable, PERFORM $M_{i}$, includes four measures of student performance: Student Achievement Test (SAT) scores for mathematical skills, SAT scores for verbal skills, proficiency in mathematics content areas for 8th graders in public school, and drop-out rates of high school students. All measures of PERFORM $M_{i}$ are obtained from the Digest of Education Statistics (1992, 1993), except dropout rates, which are obtained from the Statistical Abstract of the United States. Proficiency in mathematics content areas for 8th graders in public school and drop-out rates are only available for 1990 .

It should also be mentioned that an extensive literature exists which discusses interpretation of student performance measures. Studies, for instance, have analysed the influence of individual characteristics (Spector and Mazzeo, 1980; 
Table 2. SUR estimations of public education spending equations (dependent variable: education spending as percentage of $G S P$ )

\begin{tabular}{|c|c|c|c|c|c|c|}
\hline \multirow[b]{2}{*}{ Constant } & \multicolumn{2}{|c|}{1988} & \multicolumn{2}{|c|}{1989} & \multicolumn{2}{|c|}{1990} \\
\hline & $\begin{array}{l}2.10^{\mathrm{b}} \\
1.84\end{array}$ & $\begin{array}{l}2.05^{\mathrm{b}} \\
1.79\end{array}$ & $\begin{array}{l}2.52^{\mathrm{b}} \\
2.34\end{array}$ & $\begin{array}{l}2.38^{b} \\
2.22\end{array}$ & $\begin{array}{l}3.56^{\mathrm{b}} \\
2.82\end{array}$ & $\begin{array}{l}3.06^{\mathrm{a}} \\
2.44\end{array}$ \\
\hline Income & $\begin{array}{c}-4 \times 10^{-6} \\
0.43\end{array}$ & $\begin{array}{c}-7 \times 10^{-6} \\
0.72\end{array}$ & $\begin{array}{c}-2 \times 10^{-8} \\
0.002\end{array}$ & $\begin{aligned}- & 2 \times 10^{-6} \\
& 0.81\end{aligned}$ & $\begin{array}{c}-6 \times 10^{-6} \\
0.59\end{array}$ & $\begin{array}{l}4 \times 10^{-6} \\
0.35\end{array}$ \\
\hline Education & $\begin{array}{l}0.02 \\
1.14\end{array}$ & $\begin{array}{l}0.01 \\
0.72\end{array}$ & $\begin{array}{l}0.01 \\
0.79\end{array}$ & $\begin{array}{l}0.01 \\
0.45\end{array}$ & $\begin{array}{l}0.01 \\
0.35\end{array}$ & $\begin{array}{l}0.01 \\
0.31\end{array}$ \\
\hline Urban & $\begin{array}{c}-0.01^{\mathrm{b}} \\
2.08\end{array}$ & $\begin{array}{c}-0.01^{\mathrm{b}} \\
1.94\end{array}$ & $\begin{array}{c}-0.01^{\mathrm{a}} \\
2.82\end{array}$ & $\begin{array}{c}-0.01^{\mathrm{a}} \\
2.65\end{array}$ & $\begin{array}{c}-0.02^{\mathrm{a}} \\
3.11\end{array}$ & $\begin{array}{c}-0.02^{\mathrm{a}} \\
2.85\end{array}$ \\
\hline Student & $\begin{array}{l}0.08^{\mathrm{a}} \\
2.49\end{array}$ & $\begin{array}{l}0.08^{b} \\
2.34\end{array}$ & $\begin{array}{l}0.09^{\mathrm{a}} \\
2.87\end{array}$ & $\begin{array}{l}0.09^{\mathrm{a}} \\
2.87\end{array}$ & $\begin{array}{l}0.08^{\mathrm{b}} \\
2.27\end{array}$ & $\begin{array}{l}0.08^{b} \\
2.19\end{array}$ \\
\hline State & $\begin{array}{c}-0.002 \\
0.79\end{array}$ & $\begin{array}{c}-0.001 \\
0.52\end{array}$ & $\begin{array}{l}-0.005^{\mathrm{c}} \\
1.30\end{array}$ & $\begin{array}{c}-0.003 \\
0.98\end{array}$ & $\begin{array}{c}-0.003 \\
0.80\end{array}$ & $\begin{array}{c}-0.002 \\
0.53\end{array}$ \\
\hline Federal & $\begin{array}{r}-0.01 \\
0.62\end{array}$ & $\begin{array}{c}-0.02^{\mathrm{c}} \\
1.13\end{array}$ & $\begin{array}{c}-0.03^{c} \\
1.35\end{array}$ & $\begin{array}{r}-0.04^{\mathrm{c}} \\
1.81\end{array}$ & $\begin{array}{c}-0.05^{\mathrm{b}} \\
1.78\end{array}$ & $\begin{array}{c}-0.05^{\mathrm{b}} \\
1.87\end{array}$ \\
\hline Liberal & $\begin{array}{l}0.005^{b} \\
2.24\end{array}$ & $\begin{array}{l}0.01^{\mathrm{c}} \\
2.64\end{array}$ & $\begin{array}{l}0.01^{\mathrm{a}} \\
2.46\end{array}$ & $\begin{array}{l}0.01^{\mathrm{a}} \\
2.81\end{array}$ & $\begin{array}{l}0.01^{\mathrm{b}} \\
2.15\end{array}$ & $\begin{array}{l}0.01^{\mathrm{b}} \\
2.30\end{array}$ \\
\hline Union & $\begin{array}{l}0.004 \\
0.92\end{array}$ & $\begin{array}{l}0.005 \\
1.00\end{array}$ & $\begin{array}{l}0.004 \\
0.85\end{array}$ & $\begin{array}{l}0.004 \\
0.90\end{array}$ & $\begin{array}{l}0.01 \\
1.13\end{array}$ & $\begin{array}{l}0.01 \\
1.02\end{array}$ \\
\hline District & $\begin{array}{l}0.15^{b} \\
2.19\end{array}$ & & $\begin{array}{l}0.10^{\mathrm{c}} \\
1.48\end{array}$ & & $\begin{array}{l}0.04 \\
0.48\end{array}$ & \\
\hline Schools & & $\begin{array}{l}0.19^{\mathrm{a}} \\
3.42\end{array}$ & & $\begin{array}{l}0.15^{\mathrm{a}} \\
2.86\end{array}$ & & $\begin{array}{l}0.10^{\mathrm{c}} \\
1.62\end{array}$ \\
\hline $\begin{array}{l}R^{2} \\
\text { s.e.e. } \\
n\end{array}$ & $\begin{array}{l}0.40 \\
0.40 \\
50\end{array}$ & $\begin{array}{l}0.40 \\
0.41 \\
50\end{array}$ & $\begin{array}{l}0.40 \\
0.41 \\
50\end{array}$ & $\begin{array}{c}0.40 \\
0.41 \\
50\end{array}$ & $\begin{array}{l}0.34 \\
0.48 \\
50\end{array}$ & $\begin{array}{l}0.34 \\
0.48 \\
50\end{array}$ \\
\hline
\end{tabular}

$t$-statistics below estimated coefficients.

a, b, c: significance at $1,5,10 \%$ levels (2-tailed tests) or greater.

Leppel, 1984; Park and Kerr, 1990), the impact of differential test presentation (Marso, 1970; Schmitt and Scheirer, 1977; Gohmann and Spector, 1989), and student perception of pre-final assessed work (Mudambi, 1996) on performance. These important caveats suggest that all comparative measures of academic performance have shortcomings and also indicates a need to examine different measures of performance in our empirical study.

Median income and average education are expected to exert positive influences on test scores and negative influences on drop-out rates because higher-income and higher-educated populations are expected to demand higher educational achievement. Urbanization controls for the possibility that lower educational achievement arises in urban public schools and unionization controls for the possibility that it positively influences educational achievement. $T A K E_{i}$ controls for the percentage of high school students who, in their senior year, take the SAT test. It is expected that $T A K E_{i}$ is inversely related to test scores because, the higher are percentages of test-takers, the lower are average expected scores since larger test-taking pools suggest growing pools of lower-aptitude students.
Numbers of school districts and schools are expected to positively influence test scores and negatively influence drop-out rates since these variables reflect the degree of competition in the public education market. Eberts, Schwartz and Stone (1990) provide indirect evidence of this relationship when they conclude that, from a sample of elementary students in 287 schools, student achievement is inversely related to school size. They find that schools with more than 800 students are much less effective in fostering mathematics achievement than schools with fewer than 200 students. Greater numbers of schools may therefore lead to higher performance because they lower such factors as student-teacher ratios.

Table 3 reports SUR estimations of student performance based on mathematical and verbal SAT test scores. Median income exerts hypothesized positive and significant influences in only two of 12 regressions. Average education exerts no significant influence. Urbanization only exerts a positive and significant influence in two cases of the mathematical test scores. Unionization exerts positive and significant influences on test scores. Percentages of students taking the SAT exert hypothesized negative influences and are highly statistically 
Table 3. SUR estimations of student performance (MATH SAT)

\begin{tabular}{|c|c|c|c|c|c|c|}
\hline \multirow[b]{2}{*}{ Constant } & \multicolumn{2}{|c|}{1988} & \multicolumn{2}{|c|}{1989} & \multicolumn{2}{|c|}{1990} \\
\hline & $\begin{array}{c}496.16^{\mathrm{a}} \\
18.37\end{array}$ & $\begin{array}{c}498.67^{\mathrm{a}} \\
17.59\end{array}$ & $\begin{array}{c}479.59^{\mathrm{a}} \\
17.34\end{array}$ & $\begin{array}{c}482.66^{\mathrm{a}} \\
16.47\end{array}$ & $\begin{array}{c}496.58^{\mathrm{a}} \\
18.19\end{array}$ & $\begin{array}{c}499.14^{\mathrm{a}} \\
16.85\end{array}$ \\
\hline Income & $\begin{array}{l}0.0001 \\
0.52\end{array}$ & $\begin{array}{l}0.0001 \\
0.41\end{array}$ & $\begin{array}{l}0.0004^{\mathrm{c}} \\
1.33\end{array}$ & $\begin{array}{l}0.0003 \\
1.07\end{array}$ & $\begin{array}{l}0.0003 \\
1.06\end{array}$ & $\begin{array}{l}0.0003 \\
1.25\end{array}$ \\
\hline Education & $\begin{array}{l}0.06 \\
0.09\end{array}$ & $\begin{array}{r}-0.02 \\
0.30\end{array}$ & $\begin{array}{l}0.41 \\
0.64\end{array}$ & $\begin{array}{l}0.36 \\
0.54\end{array}$ & $\begin{array}{l}0.11 \\
0.17\end{array}$ & $\begin{array}{l}0.08 \\
0.12\end{array}$ \\
\hline Urban & $\begin{array}{l}0.26^{\mathrm{c}} \\
1.41\end{array}$ & $\begin{array}{l}0.13 \\
0.69\end{array}$ & $\begin{array}{l}0.30^{\mathrm{c}} \\
1.61\end{array}$ & $\begin{array}{l}0.17 \\
0.89\end{array}$ & $\begin{array}{l}0.20 \\
1.09\end{array}$ & $\begin{array}{l}0.05 \\
0.27\end{array}$ \\
\hline Union & $\begin{array}{l}0.36^{\mathrm{b}} \\
2.28\end{array}$ & $\begin{array}{l}0.45^{\mathrm{a}} \\
2.76\end{array}$ & $\begin{array}{l}0.35^{b} \\
2.11\end{array}$ & $\begin{array}{l}0.43^{\mathrm{a}} \\
2.60\end{array}$ & $\begin{array}{l}0.42^{\mathrm{a}} \\
2.66\end{array}$ & $\begin{array}{l}0.50^{\mathrm{a}} \\
3.03\end{array}$ \\
\hline Take & $\begin{array}{c}-1.17^{\mathrm{a}} \\
12.98\end{array}$ & $\begin{array}{r}-1.14^{\mathrm{a}} \\
11.80\end{array}$ & $\begin{array}{c}-1.25^{\mathrm{a}} \\
13.95\end{array}$ & $\begin{array}{c}-1.22^{\mathrm{a}} \\
12.48\end{array}$ & $\begin{array}{c}-1.31^{\mathrm{a}} \\
14.79\end{array}$ & $\begin{array}{c}-1.30^{\mathrm{a}} \\
13.44\end{array}$ \\
\hline Districts & $\begin{array}{l}9.96^{\mathrm{a}} \\
4.18\end{array}$ & & $\begin{array}{l}9.93^{\mathrm{a}} \\
4.06\end{array}$ & & $\begin{array}{c}10.06^{\mathrm{a}} \\
3.81\end{array}$ & \\
\hline Schools & & $\begin{array}{l}5.39^{a} \\
2.76\end{array}$ & & $\begin{array}{l}5.18^{\mathrm{a}} \\
2.64\end{array}$ & & $\begin{array}{l}4.25^{b} \\
2.19\end{array}$ \\
\hline $\begin{array}{l}R^{2} \\
\text { s.e.e. } \\
n\end{array}$ & $\begin{array}{l}0.80 \\
14.33 \\
50\end{array}$ & $\begin{array}{l}0.79 \\
14.69 \\
50\end{array}$ & $\begin{array}{l}0.81 \\
14.98 \\
50\end{array}$ & $\begin{array}{l}0.79 \\
15.39 \\
50\end{array}$ & $\begin{array}{l}0.82 \\
14.57 \\
50\end{array}$ & $\begin{array}{l}0.81 \\
15.91 \\
50\end{array}$ \\
\hline \multicolumn{7}{|c|}{ SUR estimations of student performance (VERBAL $S A T)$} \\
\hline Constant & $\begin{array}{c}476.81^{\mathrm{a}} \\
16.08\end{array}$ & $\begin{array}{c}469.78^{\mathrm{a}} \\
15.57\end{array}$ & $\begin{array}{c}476.59^{\mathrm{a}} \\
16.81\end{array}$ & $\begin{array}{c}469.37^{\mathrm{a}} \\
16.16\end{array}$ & $\begin{array}{c}471.66^{\mathrm{a}} \\
16.75\end{array}$ & $\begin{array}{c}464.85^{\mathrm{a}} \\
15.85\end{array}$ \\
\hline Income & $\begin{array}{c}7 \times 10^{-7} \\
0.24\end{array}$ & $\begin{array}{c}5 \times 10^{-5} \\
0.18\end{array}$ & $\begin{array}{l}0.0002 \\
0.73\end{array}$ & $\begin{array}{l}0.0001 \\
0.45\end{array}$ & $\begin{array}{l}0.0003 \\
1.08\end{array}$ & $\begin{array}{l}0.0003^{\circ} \\
1.39\end{array}$ \\
\hline Education & $\begin{array}{r}-0.03 \\
0.04\end{array}$ & $\begin{array}{r}-0.07 \\
0.11\end{array}$ & $\begin{array}{r}-0.03 \\
0.05\end{array}$ & $\begin{array}{r}-0.06 \\
0.09\end{array}$ & $\begin{array}{l}0.12 \\
0.19\end{array}$ & $\begin{array}{l}0.13 \\
0.19\end{array}$ \\
\hline Urban & $\begin{array}{r}-0.07 \\
0.36\end{array}$ & $\begin{array}{r}-0.07 \\
0.38\end{array}$ & $\begin{array}{r}0.11 \\
0.58\end{array}$ & $\begin{array}{r}-0.10 \\
0.55\end{array}$ & $\begin{array}{r}-0.13 \\
0.69\end{array}$ & $\begin{array}{r}-0.15 \\
0.77\end{array}$ \\
\hline Union & $\begin{array}{l}0.32^{\mathrm{b}} \\
1.82\end{array}$ & $\begin{array}{l}0.33^{\mathrm{b}} \\
1.92\end{array}$ & $\begin{array}{l}0.27^{b} \\
1.59\end{array}$ & $\begin{array}{l}0.28^{b} \\
1.72\end{array}$ & $\begin{array}{l}0.34^{\mathrm{b}} \\
2.08^{-}\end{array}$ & $\begin{array}{l}0.34^{\mathrm{b}} \\
2.09\end{array}$ \\
\hline Take & $\begin{array}{c}-1.02^{\mathrm{a}} \\
10.39\end{array}$ & $\begin{array}{c}-0.98^{\mathrm{a}} \\
9.55\end{array}$ & $\begin{array}{c}-1.08^{\mathrm{a}} \\
11.72\end{array}$ & $\begin{array}{c}-1.03^{\mathrm{a}} \\
10.58\end{array}$ & $\begin{array}{r}-1.16^{\mathrm{a}} \\
12.75\end{array}$ & $\begin{array}{c}-1.15^{\mathrm{a}} \\
11.96\end{array}$ \\
\hline Districts & $\begin{array}{l}5.32^{\mathrm{b}} \\
2.06\end{array}$ & & $\begin{array}{l}5.45^{b} \\
2.20\end{array}$ & & $\begin{array}{l}4.10^{\mathrm{c}} \\
1.52\end{array}$ & \\
\hline Schools & & $\begin{array}{l}4.67^{b} \\
2.32\end{array}$ & & $\begin{array}{l}4.79^{b} \\
2.54\end{array}$ & & $\begin{array}{l}3.05^{\mathrm{c}} \\
1.63^{2}\end{array}$ \\
\hline$R^{2}$ & 0.72 & 0.73 & 0.75 & 0.76 & 0.78 & 0.78 \\
\hline s.e.e. & 15.50 & 15.39 & 15.16 & 15.12 & 14.76 & 14.81 \\
\hline$n$ & 50 & 50 & 50 & 50 & 50 & 50 \\
\hline
\end{tabular}

$t$-statistics below estimated coefficients.

a, b, c: significance at 1, 5, 10\% levels (2-tailed tests) or greater.

significant. Both numbers of school districts and schools exert positive and significant influences on all test scores indicating substantial support for the Leviathan hypothesis.

Table 4 reports OLS estimations of the 8th grade mathematical proficiency test and high school drop-out rate equations for $1990 .{ }^{14}$ As hypothesized, median income and education exert the hypothesized and statistically significant influences on the mathematical test scores and drop-out rates. Urbanization and unionization never exert significant influences. Both numbers of school districts and schools exert statistically significant influences in directions supporting the Leviathan hypothesis.

\footnotetext{
${ }^{14}$ SUR estimation was not conducted because data for 1990 was only available for the performance measures.
} 
Table 4. OLS estimations of math proficiency and drop-out rate

\begin{tabular}{lcccc}
\hline & \multicolumn{2}{c}{ Math proficiency } & \multicolumn{2}{c}{ Drop-out rate } \\
\hline Constant & $218.01^{\mathrm{a}}$ & $203.29^{\mathrm{a}}$ & $21.82^{\mathrm{a}}$ & $23.33^{\mathrm{a}}$ \\
& 13.50 & 12.78 & 5.32 & 5.97 \\
Income & $0.001^{\mathrm{b}}$ & $0.001^{\mathrm{b}}$ & $-0.001^{\mathrm{c}}$ & $-0.001^{\mathrm{c}}$ \\
& 2.49 & 2.94 & 1.78 & 1.80 \\
Education & $0.72^{\mathrm{b}}$ & $0.66^{\mathrm{b}}$ & $-0.21^{\mathrm{b}}$ & $-0.19^{\mathrm{b}}$ \\
& 2.21 & 2.16 & 2.38 & 2.27 \\
Urban & 0.02 & 0.02 & 0.004 & 0.003 \\
& 0.16 & 0.24 & 0.15 & 0.11 \\
Union & 0.001 & 0.04 & -0.02 & -0.03 \\
& 0.01 & 0.47 & 0.79 & 1.42 \\
Districts & $7.91^{\mathrm{a}}$ & & $-1.41^{\mathrm{a}}$ & \\
& 5.65 & & 3.67 & \\
Schools & & $6.42^{\mathrm{a}}$ & & $-1.16^{\mathrm{a}}$ \\
& & 6.29 & & 4.56 \\
$R^{2}$ & 0.56 & 0.61 & 0.42 & 0.49 \\
S.e.e. & 5.93 & 5.60 & 1.81 & 1.71 \\
$F$ & 10.08 & 12.07 & 8.13 & 10.28 \\
$n$ & 50 & 50 & 50 & 50 \\
\hline
\end{tabular}

$t$-statistics below estimated coefficients.

a, b, c: significance at 1, 5, 10\% levels (2-tailed tests) or greater.

\section{CONCLUSION}

Previous tests of the Leviathan hypothesis have examined whether numbers of school districts exert negative influences on public education spending. This paper provides no support for this hypothesis. While no statistically significant relationships are found for education spending per pupil, positive and significant relationships are determined for regressions on education spending as percentages of GSP in 1988 and 1989. Broad support is also found for a positive relationship between numbers of schools and education spending (per student and as a percentage of GSP). Therefore, evidence indicates little support for the traditional treatment of the Leviathan hypothesis that greater competition lowers public spending.

This paper argues, however, that education spending by itself does not fully provide a valid test of the Leviathan hypothesis since spending, by itself, does not necessarily indicate the quality of public education programmes. This paper extends the testing of the Leviathan hypothesis by examining the relationship between public education quality and numbers of school districts and schools. Empirical evidence indicates that greater numbers of schools and school districts promote higher student achievement as evidenced by higher math and verbal SAT scores, math proficiency of 8th graders, and lower high school drop-out rates. Evidence therefore suggests that, while greater numbers of school districts and schools are, to some degree, associated with higher public education spending, higher student achievement appears to follow as well. These results suggest support of the Leviathan hypothesis since greater interschool competition fosters higher quality public education programmes. This evidence therefore also suggests that the growing monopolization of the public education market through school district consolidation has led to a deterioration of the quality of public schools. Examination of how vouchers may inject competition into the education market would appear to be a useful avenue for future research on what public policies may do to promote an improvement in the quality of the public education system.

\section{ACKNOWLEDGEMENTS}

The author acknowledges the helpful comments provided by William J. Boyes, Alden F. Shiers, Shelley Zacks, Takis Papakyriasis and an anonymous referee.

\section{REFERENCES}

Ashenfelter, O. (1971) The effect of unionization on wages in the public sector, Industrial and Labor Relations Review, 24, 191-202.

Averch, H. and Johnson, L. L. (1962) Behaviour of the firm under regulatory constraint, American Economic Review, 52, 1053-69.

Brennan, G. and Buchanan, J. M. (1980) The Power to Tax: Analytical Foundations of a Fiscal Constitution. Cambridge University Press, Cambridge.

Burnell, B. S. (1991) The effect of school district structure on education spending, Public Choice, 69, 253-264.

Couch, J. F., Shughart II, W. F. and Williams, A. L. (1993) Private school enrolment and public school performance, Public Choice, 76, 301-312.

Curme, M. A., Hirsch, B. T. and MacPherson, D. A. (1990) Union membership and contract coverage in the United States, 1983-1988, Industrial and Labor Relations Review, 44, 5-33.

Daugherty, A. F. (1984) Regulation and industrial organization, Journal of Political Economy, 92, 932-53.

Digest of Education Statistics, U.S. department of education, national center for education statistics, 1992 and 1993.

Eberts, R. W., Schwartz, E. K. and Stone, J. A. (1990) School reform, school size, and student achievement, Economic Review of Federal Reserve Bank of Cleveland, 26, 2-15.

Ehrenberg, R. D. (1973) Municipal government structure, unionization, and the wages of fire fighters, Industrial and Labor Relations Review, 27, 36-48.

Friedman, M. (1962) Capitalism and Freedom. University of Chicago Press, Chicago.

Forbes, K. F. and Zampelli, E. M. (1989) Is Leviathan a mythical beast? American Economic Review, 79, 587-96.

Gallagher, D. G. (1978) Teacher bargaining and school district expenditures, Industrial Relations, 17, 216-39.

Gohmann, S. F. and Spector, L. C. (1989) Test scrambling and student performance, Journal of Economic Education, 19, 235-8.

Grossman, P. J. (1989) Fiscal decentralization and government size: an extension, Public Choice, 62, 63-70.

Hamilton, B. W. and Macauley, M. K. (1991) Determinants and consequences of the private-public school choice, Journal of Urban Economics, 29, 282-94. 
Heil, J. B. (1991) The search for Leviathan revisited, Public Finance Quarterly, 19, 334-46.

Hirschman, A. O. (1970) Exit, Voice and Loyalty, Harvard University Press, Cambridge.

Ichniowski, C. (1980) Economic effects of the firefighters' union, Industrial and Labor Relations Review, 33, 198-211.

Joulfaian, D. and Marlow, M. L. (1990) Government size and decentralization: evidence from disaggregated data, Southern Economic Journal, 56, 1094-1102.

Joulfaian, D. and Marlow, M. L. (1991) Centralization and government competition, Applied Economics, 23, 1603-12.

Kenny, L. W. and Schmidt, A. B. (1994) The decline in the number of school districts in the US: 1950-1980, Public Choice, 79, $1-18$.

Leppel, K. (1984) The academic performance of returning and continuing college students: an economic analysis, Journal of Economic Education, 15, 46-54.

Logan, R. R. (1986) Fiscal illusion and the grantor government, Journal of Political Economy, 96, 1304-18.

Marlow, M. L. (1988) Fiscal decentralization and government size, Public Choice, 56, 259-69.

Marlow, M. L. (1992) Intergovernmental competition, voice and exit options and the design of fiscal structure, Constitutional Political Economy, 3, 73-87.

Marlow, M. L. and Orzechowski, W. P. (1986) Public sector unions and public spending, Public Choice, 89, 1-16.

Marso, R. N. (1970) Test item arrangement, testing time and performance, Journal of Educational Measurement, 7, 113-8.

Martinez-Vazquez, J. and Seaman, B. (1985) Private schooling and the Tiebout hypothesis, Public Finance Quarterly, 13, 293-318.

Mudambi, R. (1996) Insurance or signals? Student performance of pre-final assessed work, Applied Economics, 28, 321-6.

Nelson, M. A. (1986) An empirical analysis of state and local government tax structures in the context of the Leviathan model of government, Public Choice, 49, 283-94.

Nelson, M. A. (1987) Searching for Leviathan: comment and extension, American Economic Review, 77, 198-204.
Nelson, M. A. (1990) Decentralization of the subnational public sector: an empirical analysis of the determinants of local government structure in metropolitan areas in the U.S., Southern Economic Journal, 57, 443-57.

Oates, W. E. (1985) Searching for Leviathan: an empirical study, American Economic Review, 75, 748-57.

Oates, W. E. (1989) Searching for Leviathan: a reply and some further reflections, American Economic Review, 79, 578-83.

Park, K. H. and Kerr, P. M. (1990) Determinants of academic performance: a multinomial logit approach, Journal of Economic Education, 20, 101-11.

Raimondo, H. J. (1989) Leviathan and Federalism in the United States, Public Finance Quarterly, 178, 204-15.

Schmitt, J. C. and Scheirer, C. J. (1977) The effect of item order on objective tests, Teaching of Psychology, 4, 144-5.

Spector, L. C. and Mazzeo, M. (1980) Probit analysis and economic education, Journal of Economic Education, 11, 37-44.

Statistical Abstract of the United States (selected years). U.S. Department of Commerce.

Tiebout, C. M. (1956) A pure theory of local expenditures, Journal of Political Economy, 64, 416-24.

Trejo, S. J. (1991) Public sector unions and municipal employment, Industrial and Labor Relations Review, 45, 166-81.

Wallis, J. J. and Oates, W. E. (1988) Does economic sclerosis set in with age? An empirical study of the Olson hypothesis, Kyklos, 41, 397-417.

Winer, S. L. (1983) Some evidence on the effect of the separation of spending and taxing decisions, Journal of Political Economy, 91, $126-40$.

Zax, J. S. (1989) Is there a Leviathan in your neighborhood? American Economic Review, 79, 560-67.

Zax, J. and Ichniowski, C. (1988) The effects of public sector unionism on pay, employment, department budgets, and municipal expenditures, in When Public Sector Workers Unionize, R. B. Freeman and C. Ichniowski (eds), The University of Chicago Press, Chicago. 